\title{
Pengaruh Profitabilitas pada Kebijakan Dividen dengan Investment Opportunity Set sebagai Variabel Pemediasi
}

\author{
Ida Ayu Nabila Meidyna ${ }^{1}$ \\ Fakultas Ekonomi dan Bisnis \\ Universitas Udayana, Indonesia \\ Email: nabilameidyana@gmail.com
}

\author{
Made Mertha ${ }^{2}$ \\ Fakultas Ekonomi dan Bisnis \\ Universitas Udayana, Indonesia
}

\begin{abstract}
ABSTRAK
Kebijakan dividen perusahaaan menentukan besarnya dividen yang dibagikan kepada pemegang saham. Penelitian ini bertujuan untuk memperoleh bukti secara empiris mengenai pengaruh profitabilitas pada kebijakan dividen dengan investment opportunity set sebagai variabel pemediasi. Penelitian ini dilakukan pada perusahaan yang tergolong indeks LQ45 di BEI. Metode penentuan sampel yang digunakan adalah purposive sampling sehingga diperoleh 87 pengamatan. Teknik analisis data yang digunakan yaitu analisis jalur. Berdasarkan hasil penelitian, diketahui bahwa profitabilitas berpengaruh positif pada investment opportunity set. Profitabilitas berpengaruh positif pada kebijakan dividen. Investment opportunity set berpengaruh negatif pada kebijakan dividen. Investment opportunity set mampu memediasi pengaruh profitabilitas pada kebijakan dividen.
\end{abstract}

Kata Kunci: Profitabilitas; Investment Opportunity Set; Kebijakan Dividen.

The Effect of Profitability on Dividend Policy with Investment Opportunity Set as a Mediating Variable

\section{ABSTRACT}

The company dividend policy determines the amount of dividends distributed to shareholders. This study aims to obtain evidence of profitability in dividend policy with investment opportunities determined as mediating variables. This research was conducted at companies belonging to the LQ45 index on the IDX. The sampling method used was purposive sampling to obtain 87 observations. Data analysis technique used is path analysis. Based on research results, it is known that profitability has a positive effect on investment opportunity set. Profitability has a positive effect on dividend policy. Investment opportunity set has a negative effect on dividend policy. Investment opportunity set is able to mediate the effect of profitability on dividend policy.

Keywords: $\quad$ Profitability; Investment Opportunity Set, Dividend Policy.

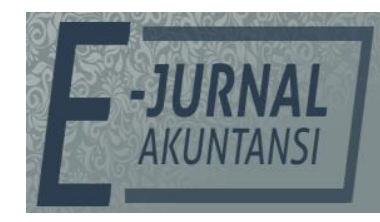

E-JA

e-Jurnal Akuntansi e-ISSN 2302-8556

Vol. 30 No. 1

Denpasar, Januari 2020

Hal. 212-225

Artikel Masuk: 20 November 2019

Tanggal Diterima: 26 Desember 2019 


\section{PENDAHULUAN}

Pasar modal berperan penting dalam perkembangan perekonomian suatu negara. Pasar modal dapat berperan sebagai sumber pendanaan eskternal perusahaan disamping perbankan. Perusahaan dapat memperoleh memperoleh dana dari investor berupa kepemilikan saham, baik melalui Initial Public Offering (IPO) yaitu ketika saham belum tercatat di bursa atau seasoned new issues yaitu ketika saham dijual secara terbuka ketika perusahaan telah going public (Azmi dan Agung, 2014). Investor melakukan investasi di pasar modal bertujuan untuk mendapatkan keuntungan pengembalian investasi melalui dividen atau pembagian keuntungan kepada pemegang saham maupun capital gain yaitu keuntungan yang diperoleh investor dari selisih harga jual terhadap harga beli suatu saham. Investor cenderung lebih menyukai pembagian dividen yang stabil karena kepercayaan investor terhadap perusahaan akan meningkat sehingga dapat menghindari risiko ketidakpastian investor dalam berinvestasi pada suatu perusahaan. Dividen merupakan pembagian laba atau keuntungan kepada pemegang saham sesuai dengan porsi kepemilikan.

Hampir seluruh perusahaan yang tercatat di Bursa Efek Indonesia membagikan dividen setiap tahunnya termasuk perusahaan yang tergolong indeks. Salah satu indeks saham di Bursa Efek Indonesia yang terdiri dari 45 emiten yang memiliki likuiditas yang tinggi serta kapitalisasi pasar terbesar disebut dengan indeks LQ45. Walaupun saham yang masuk pada indeks saham LQ45 memiliki kinerja yang baik, namun dividen yang diberikan oleh perusahaan yang masuk pada indeks saham LQ45 juga fluktuatif setiap tahunnya. Kebijakan dividen perusahaan tergambar pada dividen payout rationya, yaitu persentase laba perusahaan yang dibayarkan kepada pemegang saham berupa dividen kas. Berikut pada tabel 1 disajikan nilai Dividend Payout Ratio pada beberapa perusahaan LQ45 selama tahun 2014-2017.

Tabel 1. Dividend Payout Ratio Perusahaan Indeks LQ45 Periode 2014-2017

\begin{tabular}{lllll}
\hline Nama Perusahaan & \multicolumn{4}{l}{ Dividend Payout Ratio (\%) } \\
\hline & 2014 & 2015 & 2016 & 2017 \\
Adhi Karya Tbk. & 19,84 & 20,08 & 0,00 & 19,94 \\
Chandra Asri Petrochemical Tbk. & 0,00 & 0,00 & 0,00 & 31,58 \\
Wijaya Karya Tbk. & 16,40 & 17,80 & 26,48 & 17,74 \\
Unilever Indonesia Tbk. & 44,67 & 99,88 & 99,69 & 99,67 \\
\hline
\end{tabular}

Sumber : www.idx.co.id

Tabel 1. menunjukkan Dividend Payout Ratio perusahaan Indeks LQ45 fluktuatif setiap tahunnya serta terdapat emiten yang tidak membayarkan dividen yaitu Adhi Karya Tbk. pada tahun 2016 dan Chandra Asri Petrochemical Tbk. yang berturut-turut tidak membagikan dividen pada tahun 2014-2016. Fenomena ini mengindikasikan bahwa terdapat faktor-faktor yang berpengaruh terhadap keputusan perusahaan dalam membagikan dividen.

Dividen diperoleh dari laba bersih perusahaan, seharusnya jika laba bersih perusahaan mengalami peningkatan maka dividen dibayarkan juga akan meningkat. Kenyataannya, dividen yang dibagikan oleh perusahaan tidak selalu meningkat mengikuti meningkatnya laba bersih yang diperoleh. Kasus ini terjadi pada perusahaan Wijaya Karya Tbk. Meski terjadi kenaikan laba di tahun 2014, tercatat terjadi penurunan dividen yang dibagikan oleh perusahaan 
dibandingkan tahun sebelumnya. Laba bersih yang diperoleh perusahaan mencapai Rp 615,18 miliar, namun hanya 20\% atau Rp 123 miliar yang digelontorkan dalam bentuk dividen. Dibandingkan tahun 2013, laba bersih hanya mencapai Rp 569,9 miliar, sedangkan 30\%nya atau Rp 170,97 miliar dibagikan dalam bentuk dividen. Penurunan porsi dividen tersebut diungkapkan sebagai langkah persiapan capital expenditure untuk menunjang investasi perusahaan (www.cnnindonesia.com). Temuan ini mengindikasikan bahwa meningkatnya laba bersih perusahaan tidak selalu memengaruhi pembagian dividen karena adanya kesempatan investasi yang menguntungkan.

Kebijakan dividen perusahaan akan menentukan jumlah dividen yang akan dibagikan kepada pemegang saham sesuai dengan porsi kepemilikannya. Kebijakan dividen adalah suatu keputusan perusahaan dalam menetapkan porsi dari laba perusahaan yang akan dibagikan kepada pemegang saham dan yang ditahan dalam perusahaan untuk diivestasikan kembali (Arjana dan Dharma, 2017). Perubahan kebijakan dividen akan menghasilkan dampak yang berlawanan yaitu ketika dividen dibayarkan seluruhnya maka kepentingan cadangan perusahaan akan terabaikan, namun ketika semua laba ditahan sebagai cadangan perusahaan maka kepentingan pemegang saham yang akan terabaikan. Keadaan ini akan menimbulkan dilema bagi perusahaan untuk menentukan laba yang diperoleh akan dibagikan dalam bentuk dividen kepada pemegang saham, atau menjadikan laba sebagai laba ditahan untuk investasi kembali. Dampak tersebut dapat diminimalisir dengan melakukan pembagian dividen yang optimal sehingga terjad keseimbangan antara dividen yang dibagikan dengan pertumbuhan perusahaan di masa mendatang. Konsep ini berhubungan dengan teori keagenan karena manajemen sebagai agen telah dikontrak oleh principal dalam hal ini pemegang saham dengan memberikan wewenang dalam menetapkan kebijakan dividen. Pemegang saham lebih menyukai laba yang dihasilkan dibagikan sebagian kepada mereka sebagai dividen sedangkan manajemen lebih memilih laba yang dihasilkan sebagian besar ditahan oleh perusahaan untuk diinvestasikan kembali (Kajola et al., 2015).

Profitabilitas menjadi indikator terpenting yang dapat menunjukkan kemampuan perusahaan membayarkan dividen karena profitabilitas menggambarkan laba perusahaan pada periode tertentu. Dividen diperoleh dari laba bersih perusahaan sehingga laba bersih akan memengaruhi jumlah dividen yang akan dibagikan. Telah banyak dilakukan penelitian mengenai pengaruh profitabilitas pada kebijakan dividen namun hasil yang diperoleh tidak konsisten. Penelitian mengenai profitabilitas oleh Arjana dan Dharma (2017), (Mawutor dan Embele, 2015), Titus dan Ambrose (2015) memperoleh hasil profitabilitas berpengaruh positif dan signifikan pada kebijakan dividen. Penelitian tersebut menunjukkan hasil yang bertentangan dengan penelitian Kaźmierska dan Jóźwiak (2015) dan Anam et al. (2016), Thirumagal dan Vasantha (2017), Hasana et al (2018), Anjarsari et al (2018) yang memperoleh hasil bahwa profitabilitas berpengaruh negatif pada kebijakan dividen tunai. Hasil penelitian tersebut tidak sejalan dengan penelitian Sakir dan Fadli (2014) serta Sari dan Budiasih (2016) yang menemukan hasil bahwa variabel profitabilitas tidak berpengaruh pada kebijakan dividen. 
Investment Opportunity Set (IOS) juga dapat digunakan sebagai pertimbangan dalam pembayaran dividen karena dapat menjadi tolak ukur dalam melihat nilai perusahaan. Investment Opportunity Set adalah komponen dari nilai perusahaan yang menjadi alternatif pilihan yang akan digunakan dalam melakukan keputusan berinvestasi di masa mendatang (Anugrah dan Bagus, 2009). Penelitian mengenai variabel investment opportunity set yang dilakukan oleh Gunawan dan Tobing, (2018), Prakoso (2016), Siboni dan Pourali (2015), dan Sari., et al (2014) menyatakan bahwa investment opportunity set berpengaruh positif pada kebijakan dividen. Hasil penelitian ini bertentangan dengan penelitian yang dilakukan oleh Yudiana dan Yadnyana (2016) menyatakan bahwa IOS berpengaruh negatif pada kebijakan dividen. Penelitian oleh Sarmento et al (2014), Haryetti dan Ekayanti (2012) menemukan hasil yang berbeda yaitu investment opportunity set tidak berpengaruh signifikan terhadap kebijakan dividen.

Hasil penelitian terdahulu menyatakan adanya inkonsistensi hasil penelitian tentang pengaruh profitabilitas pada kebijakan dividen. Hasil dari penelitian sebelumnya yang tidak konsisten menyebabkan dijadikannya investment opportunity set sebagai variabel mediasi di dalam penelitian ini. IOS diduga turut memengaruhi hubungan profitabilitas dengan kebijakan dividen menjadi hubungan yang tidak langsung. Investment Opportunity Set merupakan perantara hubungan antara profitabilitas dengan kebijakan dividen. IOS dapat menjelaskan pengaruh tidak langsung profitabilitas terhadap kebijakan dividen. Perusahaan yang memiliki kesempatan investasi tinggi, diiringi dengan profitabilitas yang tinggi maka kemungkinan perusahaan akan membayarkan dividen dengan jumlah yang rendah karena perusahaan memutuskan untuk mereinvestasi dananya sebagai laba ditahan dibandingkan membagikannya dalam bentuk dividen. Residual dividend policy theory menyatakan dividen dibayarkan oleh perusahaan jika terdapat kelebihan dana dari laba yang diperoleh setelah digunakan untuk membiayai investasi menguntungkan yang direncanakan.

Kerangka konseptual dari penelitian akan ditambilkan pada Gambar 1.

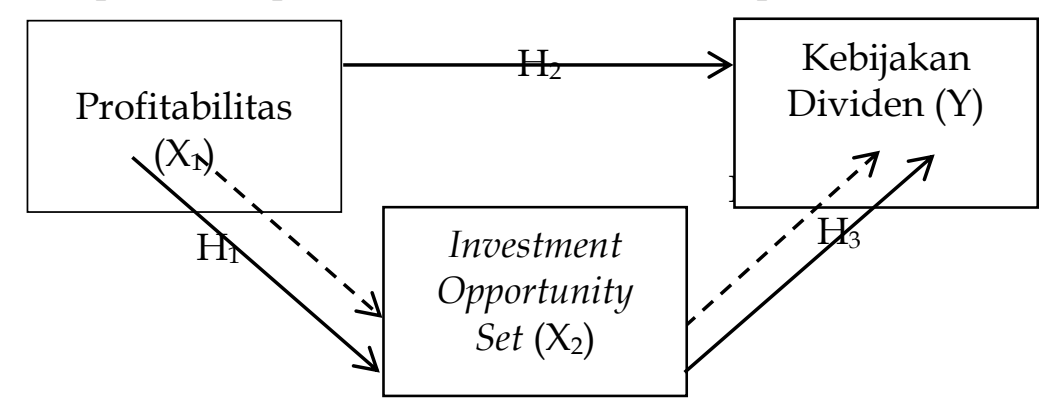

\section{Gambar 1. Kerangka Konseptual}

Sumber : Data Penelitian, 2019

Berdasarkan pecking order theory, perusahaan lebih menyukai pendanaan dari sumber internal sehingga perusahaan akan menggunakan laba ditahan untuk membiayai investasi. Baskin (1989) menyatakan jika profitabilitas semakin tinggi maka peluang investasi perusahaan akan semakin besar. Penelitian yang dilakukan Afriadi (2016) juga menyatakan profitabilitas berpengaruh positif dan 
siginifikan terhadap investment opportunity set sehingga dengan profitabilitas yang tinggi perusahaan akan mampu menghasilkan jumlah laba yang optimal dengan menambah jumlah laba ditahan maka akan meningkatkan kesempatan perusahaan untuk melakukan investasi. Profitabilitas diproksikan dengan menggunakan rasio Return on Asset (ROA). ROA memberikan informasi mengenai seberapa efisien manajemen dalam menggunakan asetnya untuk menghasilkan pendapatan (Bista et al., 2018). Hasil penelitian ini juga didukung oleh penelitian Subchan dan Sudarman (2010), Saputro dan Lela (2007), Lestari (2004) yang menemukan hasil profitabilitas memiliki pengaruh positif dan signifikan terhadap IOS. Berdasarkan uraian diatas, hipotesis yang dirumuskan adalah :

$\mathrm{H}_{1}$ : Profitabilitas berpengaruh positif pada investment opportunity set.

Bhattacharya (1979) menjelaskan tentang pembayaran dividen yang optimal sebagai sinyal dari profitabilitas di masa depan. Kemampuan perusahaan dalam melakukan pembayaran dividen dapat menjadi sinyal bagi investor. Pernyataan tersebut didukung oleh teori sinyal yaitu peningkatan kebijakan dividen dapat menjadi sinyal bagi investor mengenai prospek perusahaan dan gambaran masa depan perusahaan yang baik. Berdasarkan hasil penelitian Silaban dan Purnawati (2016) diperoleh hasil bahwa profitabilitas berpengaruh positif pada kebijakan dividen. Keuntungan perusahaan berupa laba yang diperoleh akan memengaruhi besarnya dividen yang dibagikan. Menurut Khalid dan Mobeen (2015) perusahaan membayarkan dividen sesuai dengan pendapatannya jika perusahaan memiliki profitabilitas yang tinggi dalam return asset. Hasil penelitian yang sama dikemukakan oleh Yudiana dan Yadnyana (2016), Yunisari dan Ratnadi (2018), Ginting (2018), serta Singla dan Pradeepta (2018) bahwa profitabilitas berpengaruh positif pada kebijakan dividen. Berdasarkan uraian diatas, hipotesis yang dirumuskan adalah:

$\mathrm{H}_{2}$ : Profitabilitas berpengaruh positif pada kebijakan dividen.

Berdasarkan pecking order theory, perusahaan cenderung untuk menggunakan sumber dana yang berasal dari internal dibandingkan sumber dana eksternal. Laba ditahan yang sebagian besar merupakan sumber dana internal berpengaruh pada pembayaran dividen jika perusahaan tersebut memiliki IOS yang menguntungkan. Pecking order theory diperkuat oleh hasil penelitian dari Yudiana dan Yadnyana (2016) yaitu IOS berpengaruh negatif terhadap kebijakan dividen karena perusahaan dengan investment opportunity yang tinggi akan membagikan dividen lebih rendah karena perusahaan menginginkan dana tersebut untuk diinvestasikan kembali untuk pengembangan perusahaan. Penelitian tersebut konsisten dengan penelitian Subramaniam et al (2011) dan Natalia (2013) hasil IOS berpengaruh negatif pada kebijakan dividen. Berdasarkan uraian diatas, hipotesis yang dirumuskan adalah:

$\mathrm{H}_{3}$ : Investment opportunity set berpengaruh negatif pada kebijakan dividen.

Berdasarkan Residual Dividend Policy Theory, perusahaan melakukan pembagian dividen apabila memiliki sisa dana setelah mendanai seluruh investasi yang menguntungkan dengan menggunakan laba ditahan perusahaan. Residual Dividend Policy Theory adalah teori yang menyatakan perusahaan membayar sebagai dividen dari semua arus kas yang dimiliki setelah membiayai 
investasi yang menguntungkan (Miller dan Modigliani, 1961). Perusahaan akan membayarkan nol dividen dalam satu tahun karena perusahaan membutuhkan dana untuk membiayai kesempatan investasi yang menguntungkan, namun tahun selanjutnya mungkin perusahaan dapat membagikan dividen dengan jumlah yang tinggi karena peluang investasi yang tidak menguntungkan.

Perusahaan dengan profitabilitas yang tinggi, serta memiliki IOS yang tinggi maka lebih baik untuk menahan laba yang dimiliki untuk diinvestasikan kembali dibandingkan membagikannya dalam bentuk dividen. Investment opportunity set dapat menjadi perantara hubungan antara profitabilitas dengan kebijakan dividen karena menyebabkan pengaruh profitabilitas terhadap kebijakan dividen menjadi pengaruh tidak langsug. Penelitian yang dilakukan Rahmawati (2012) membuktikan bahwa investment opportunity set mampu memediasi pengaruh profitabilitas pada kebijakan dividen. Berdasarkan uraian diatas, hipotesis yang dirumuskan adalah :

$\mathrm{H}_{4}$ : Profitabilitas berpengaruh pada kebijakan dividen melalui investment opportunity set.

\section{METODE PENELITIAN}

Penelitian ini menggunakan metode kuantitatif yang berbentuk asosiatif. Metode penelitian kuantitatif merupakan metode ilmiah untuk meneliti suatu populasi dan sampel tertentu yang bertujuan untuk menguji hipotesis yang telah dirumuskan dengan menggunakan data yang telah dikumpulkan (Sugiyono 2017:23). Penelitian yang dilakukan berbentuk asosiatif yaitu penelitian yang digunakan dalam menguji hipotesis hubungan antara dua variabel atau lebih (Sugiyono 2017:20). Sumber data dalam penelitian ini adalah sumber data sekunder, yaitu data yang diperoleh peneliti dari berbagai sumber yang telah ada yaitu dari urnal-jurnal penelitian terdahulu, teori-teori yang ada pada buku pustaka, dan data keuangan perusahaan-perusahaan yang tergolong indeks LQ45 di Bursa Efek Indonesia tahun 2015-2017.

Variabel yang dianalisis dalam penelitian ini diantaranya adalah variabel bebas, variabel pemediasi, dan variabel terikat. Variabel bebas dalam penelitian ini adalah profitabilitas. Profitabilitas adalah perbandingan yang digunakan untuk menghasilkan laba yang bergantung pada model yang digunakan. Variabel pemediasi dalam penelitian ini adalah investment opportunity set. Investment opportunity set adalah pilihan-pilihan investasi yang bisa didapatkan dimasa mendatang. Variabel terikat dalam penelitian ini adalah kebijakan dividen. Kebijakan dividen merupakan keputusan perusahaan untuk menentukan berapa besarnya laba bersih yang akan dibagikan ke dalam bentuk dividen bagi pemegang saham.

Populasi yang digunakan adalah perusahaan yang tergolong indeks LQ45 tahun 2015-2017. Metode pengambilan sampel yang digunakan dalam penelitian ini adalah non probability sampling dengan teknik purposive sampling, yaitu teknik penentuan sampel dengan pertimbangan tertentu sehingga sampel yang dibentuk dapat mewakili sifat-sifat populasi (Sugiyono, 2017:85). Beberapa kriteria yang digunakan adalah perusahaan yang tergolong indeks saham LQ45 membagikan dividen berturut-turut selama tahun 2015-2017 dan menerbitkan laporan keuangannya di Bursa Efek Indonesia, perusahaan yang tergolong 
indeks saham LQ45 di dalam laporan keuangannya memuat angka untuk menghitung proksi pada variabel yang diteliti. Teknik pengumpulan data yang digunakan dalam penelitian ini adalah metode observasi non partisipasi. Peneliti melakukan penelitian ini pada data yang bersumber dari laporan keuangan perusahaan yang tergolong indeks saham LQ45 di Bursa Efek Indonesia tahun 2015-2017 pada web www.idx.co.id. Analisis data yang digunakan adalah uji statistik deskriptif, uji asumsi klasik, analisis jalur, dan uji sobel.

\section{HASIL DAN PEMBAHASAN}

Berikut pada Tabel 2 yang memperlihatkan secara rinci proses seleksi pemilihan sampel penelitian.

Tabel 2. Seleksi Pemilihan Sampel

\begin{tabular}{lll}
\hline No & Keterangan & $\begin{array}{l}\text { Jumlah } \\
\text { Perusahaan }\end{array}$ \\
\hline 1 & Perusahaan yang masuk dalam indeks LQ45 & 45 \\
2 & $\begin{array}{l}\text { Perusahaan indeks LQ45 yang tidak } \\
\text { membagikan dividen selama tahun buku }\end{array}$ & $(16)$ \\
& 2015-2017 & \\
3 & Jumlah sampel penelitian & 29 \\
& Tahun pengamatan (2015-2017) & 3 \\
& Total sampel selama periode penelitian & 87 \\
\hline
\end{tabular}

Sumber : Data Penelitian, 2019

Tabel 2 diatas menunjukkan bahwa saham yang terdaftar di Indeks LQ45 berjumlah 45 perusahaan. Terdapat 16 perusahaan yang tidak membagikan dividen selama tahun buku 2015-2017. Berdasarkan data tersebut, diperoleh sampel sejumlah 87 selama periode penelitian. Hasil dari pengujian statistik deskriptif penelitian dapat dilihat pada tabel 3.

Tabel 3. Hasil Analisis Statistik Deskriptif

\begin{tabular}{llllll}
\hline & & & & & Std. \\
& N & Minimum & Maximum & Mean & Deviation \\
\hline ROA & 87 & 0,0541 & 45,7885 & 10,6653 & 10,71362 \\
IOS & 87 & $-16,7928$ & 72,6282 & 11,9747 & 18,05347 \\
DPR & 87 & 4,1887 & 174,8252 & 47,7409 & 32,809671 \\
Valid N (listwise) & 87 & & & & \\
\hline
\end{tabular}

Sumber : Data Penelitian, 2019

Tabel 3 menunjukkan hasil analisis statistik deskriptif masing-masing variabel. Profitabilitas menunjukkan nilai minimum sebesar 0,0541, nilai maksimum sebesar 45,7885, nilai rata-rata (mean) sebesar 10,6653 dan standar deviasi sebesar 10,71362. Investment Opportunity Set memiliki nilai minimum sebesar $-16,7928$, nilai maksimum sebesar 72,6282, nilai rata-rata (mean) sebesar 11,9747 dan standar deviasi sebesar 18,05347. Kebijakan dividen memiliki nilai minimum sebesar 4,1887, nilai maksimum sebesar 174,8252, nilai rata-rata (mean) sebesar 47,7409, dan standar deviasi sebesar 32,809671. 
Tabel 4. Hasil Analisis Jalur Struktur 1

\begin{tabular}{|c|c|c|c|c|c|}
\hline \multirow[t]{2}{*}{ Model } & \multicolumn{2}{|c|}{$\begin{array}{l}\text { Unstandardized } \\
\text { Coefficients }\end{array}$} & \multicolumn{2}{|c|}{$\begin{array}{l}\text { Standardized } \\
\text { Coefficients }\end{array}$} & \multirow[b]{2}{*}{ Sig. } \\
\hline & $\mathrm{B}$ & Std. Error & Beta & & \\
\hline (Constant) & 0,006 & 0,086 & & 0,075 & 0,940 \\
\hline Profitabilitas & 0,322 & 0,070 & 0,445 & 4,586 & 0,000 \\
\hline R Square & 0,198 & & & & \\
\hline Adjusted R Square & 0,189 & & & & \\
\hline F Statistik & 21,033 & & & & \\
\hline Signifikansi Uji F & 0,000 & & & & \\
\hline
\end{tabular}

Sumber : Data Penelitian, 2019

Persamaan struktural analisis jalur struktur 1 adalah :

$$
\begin{gathered}
X_{2}=\beta_{1} X_{1}+e_{1} \\
X_{2}=0,445 X_{1}+e_{1}
\end{gathered}
$$

\begin{tabular}{|c|c|c|c|c|c|}
\hline \multirow[t]{2}{*}{ Model } & \multicolumn{2}{|c|}{$\begin{array}{l}\text { Unstandardized } \\
\text { Coefficients }\end{array}$} & \multicolumn{2}{|c|}{$\begin{array}{l}\text { Standardized } \\
\text { Coefficients }\end{array}$} & \multirow[b]{2}{*}{ Sig. } \\
\hline & $\mathrm{B}$ & Std. Error & Beta & $\mathrm{t}$ & \\
\hline (Constant) & $-0,221$ & 0,061 & & $-3,599$ & 0,001 \\
\hline Profitabilitas & 0,277 & 0,056 & 0,484 & 4,966 & 0,000 \\
\hline Investment Opportunity Set & $-0,158$ & 0,077 & $-0,199$ & $-2,042$ & 0,044 \\
\hline R Square & 0,360 & & & & \\
\hline Adjusted R Square & 0,345 & & & & \\
\hline F Statistik & 23,616 & & & & \\
\hline Signifikansi Uji F & 0,000 & & & & \\
\hline
\end{tabular}

Tabel 5. Hasil Analisis Jalur Struktur 2

Sumber : Data Penelitian, 2019

Persamaan struktural analisis jalur struktur 2 adalah :

$$
\begin{gathered}
Y=\beta_{2} X_{1}+\beta_{2} X_{2}+e_{2} \\
Y=0,484 X_{1}-0,199 X 2+e_{2}
\end{gathered}
$$

\begin{tabular}{|c|c|c|c|c|c|c|}
\hline Regresi & $\begin{array}{l}\text { Koef. } \\
\text { Standar }\end{array}$ & Reg. & $\begin{array}{l}\text { Standard } \\
\text { Error }\end{array}$ & t hitung & $\begin{array}{l}\text { Tingkat } \\
\text { Signifikansi }\end{array}$ & Keterangan \\
\hline$X_{1} \rightarrow X_{2}$ & 0,445 & & 0,070 & 4,586 & 0,000 & Signifikan \\
\hline$X_{1} \rightarrow Y$ & 0,484 & & 0,056 & 4,966 & 0,000 & Signifikan \\
\hline$X_{2} \rightarrow$ & $-0,199$ & & 0,077 & $-2,042$ & 0,044 & Signifikan \\
\hline
\end{tabular}

Tabel 6. Ringkasan Koefisien Jalur dan Signifikansi Hubungan Antarvariabel

Sumber : Data Penelitian, 2019

Berdasarkan pengujian pengaruh Profitabilitas terhadap Investment Opportunity Set, signifikansi sebesar 0,000 dan koefisien beta 0,445. Nilai Signifikansi 0,000 $<0,05$ mengindikasikan bahwa $\mathrm{H}_{1}$ diterima yang berarti profitabilitas berpengaruh positif pada Investment Opportunity Set. Berdasarkan pengujian pengaruh profitabilitas terhadap kebijakan dividen diperoleh signifikansi sebesar 0,000 dengan koefisien beta 0,484. Signifikansi 0,000<0,05 mengindikasikan bahwa $\mathrm{H}_{2}$ diterima yang berarti bahwa profitabilitas berpengaruh positif dan pada kebijakan dividen. Berdasarkan pengujian pengaruh IOS pada kebijakan dividen diperoleh nilai signifikansi sebesar 0,044 dengan nilai koefisien beta -0,199. Nilai Signifikansi 0,044 $<0,050$ mengindikasikan bahwa $\mathrm{H}_{3}$ diterima yang berarti bahwa Investment Opportunity Set berpengaruh negatif pada kebijakan dividen. 
Pemeriksaan validitas model pada analisis jalur dilandasi oleh dua indikator, yaitu koefisien determinasi total dan metode trimming. Perhitungan standar error struktur 1 adalah sebagai berikut:

$\mathrm{e}_{1}=\sqrt{1-R_{1}^{2}}=\sqrt{1-0,189}=0,900$

Perhitungan standar error struktur 2 adalah sebagai berikut:

$\mathrm{e}_{2}=\sqrt{1-R_{2}{ }^{2}}=\sqrt{1-0,345}=0,809$

Koefisien determinasi total adalah sebesar:

$\mathrm{R}^{2}{ }_{\mathrm{m}} \quad=1-\left(\mathrm{e}_{1}\right)^{2}\left(\mathrm{e}_{2}\right)^{2}$

$$
\begin{aligned}
& =1-(0,900)^{2}(0,809)^{2} \\
& =1-(0,810)(0,654)
\end{aligned}
$$$$
=1-0,529=0,471
$$

Koefisien determinasi total bernilai 0,471 berarti sebesar $47,1 \%$ variasi kebijakan dividen dipengaruhi oleh variasi profitabilitas dan Investment Opportunity Set, sisanya sebesar 52,9\% djelaskan oleh variabel lain diluar model yang digunakan dalam penelitian. Apabila disajikan menjadi model jalur maka akan terlihat seperti pada gambar 2. sebagai berikut:

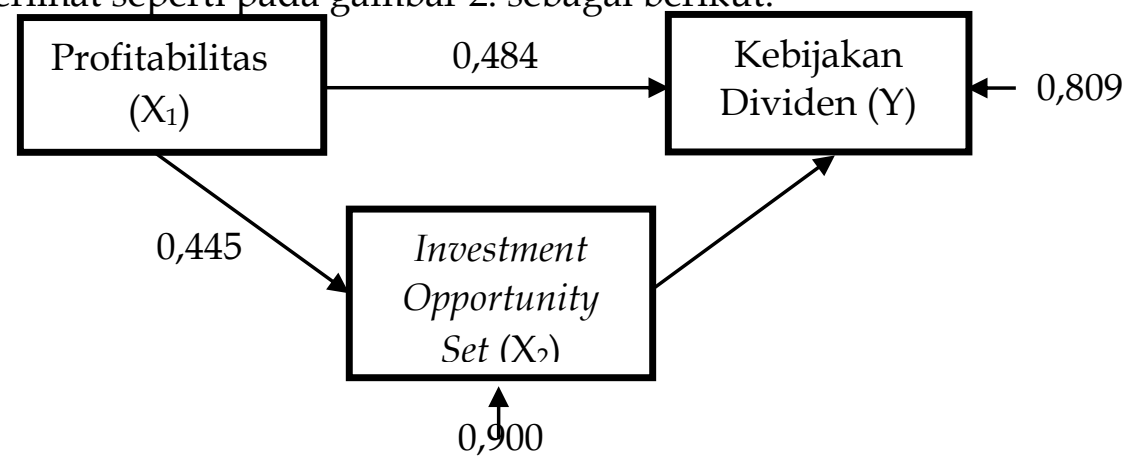

Gambar 1. Validasi Model Diagram Jalur Akhir

Sumber : Data Penelitian, 2019

Tabel 7. menunjukkan bahwa pengaruh langsung profitabilitas terhadap Investment Opportunity Set adalah sebesar 0,445. Pengaruh langsung variabel profitabilitas terhadap kebijakan dividen sebesar 0,484. Pengaruh langsung variabel IOS pada kebijakan dividen adalah sebesar -0,199, berarti kebijakan dividen lebih besar dipengaruhi oleh profitabilitas dibandingkan Investment Opportunity Set. Sedangkan pengaruh tidak langsung variabel profitabilitas terhadap kebijakan dividen melalui Investment Opportunity Set sebesar -0,088. Pengaruh total profitabilitas pada kebijakan dividen melalui IOS sebesar 0,396. Lebih besar total pengaruh profitabilitas terhadap kebijakan dividen secara langsung dibandingkan pengaruh tidak langsung profitabilitas terhadap kebijakan dividen melalui variabel Investment Opportunity Set.

Uji sobel merupakan pengujian untuk mengetahui hubungan variabel melalui sebuah variabel mediasi. Tujuan dari uji sobel adalah mengetahui kekuatan pengaruh tidak langsung variabel profitabilitas $\left(X_{1}\right)$ pada kebijakan dividen $(\mathrm{Y})$ melalui investment opportunity set $\left(\mathrm{X}_{2}\right)$. Kriteria pengujian yang digunakan adalah sebagai berikut : (1) Jika $\mathrm{Z}$ hitung $\leq 1,96$ maka $\mathrm{H}_{0}$ diterima, 
berarti Investment Opportunity Set bukan merupakan variabel mediasi, (2) Jika Z hitung $>$ 1,96 maka $\mathrm{H}_{0}$ ditolak, berarti Investment Opportunity Set merupakan variabel mediasi. Untuk menguji signifikansi pengaruh tidak langsung maka nilai $\mathrm{z}$ dari koefisien ab dihitung dengan rumus sebagai berikut :

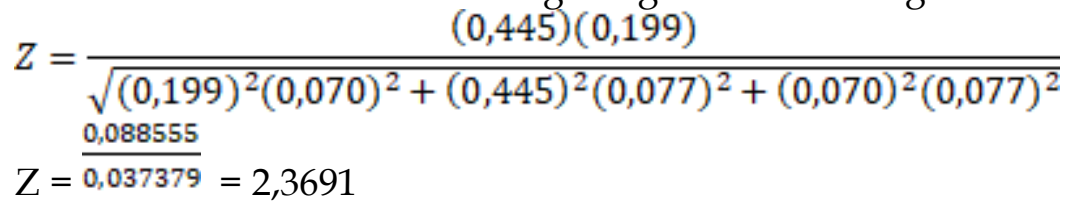

Tabel 7. Pengaruh Langsung dan Pengaruh Tidak Langsung serta Pengaruh Total Variabel Penelitian

\begin{tabular}{|c|c|c|c|}
\hline $\begin{array}{l}\text { Pengaruh } \\
\text { Variabel }\end{array}$ & $\begin{array}{l}\text { Pengaruh } \\
\text { Langsung }\end{array}$ & $\begin{array}{l}\text { Pengaruh Tidak Langsung Melalui } \\
\text { Investment Opportunity Set } \\
\left(\beta_{1} \times_{3} \beta_{3}\right.\end{array}$ & $\begin{array}{l}\text { Pengaruh } \\
\text { Total }\end{array}$ \\
\hline $\mathrm{X} 1 \rightarrow \mathrm{X} 2$ & 0,445 & - & 0,445 \\
\hline $\mathrm{X} 1 \rightarrow \mathrm{Y}$ & 0,484 & $-0,088$ & 0,396 \\
\hline $\mathrm{X} 2 \rightarrow \mathrm{Y}$ & $-0,199$ & - & $-0,199$ \\
\hline
\end{tabular}

Oleh karena Z hitung sebesar 2,3691 > 1,96. Artinya Investment Opportunity Set (X2) merupakan variabel yang memediasi profitabilitas (X1) terhadap kebijakan dividen (Y) atau dengan kata lain profitabilitas berpengaruh secara tidak langsung terhadap kebijakan dividen melalui Investment Opportunity Set.

Implikasi dari penelitian ini berupa implikasi teoritis dan praktis. Secara teoritis penelitian yang dilakukan diharapkan menyumbangkan kontribusi mengenai pengaruh profitabilitas pada kebijakan dividen dengan investment opportunity set sebagai variabel pemediasi pada perusahaan yang tergolong indeks LQ45 di BEI. Penelitian ini juga mendukung teori keagenan, residual dividend policy theory, pecking order theory, serta teori sinyal. Penelitian ini mengonfirmasi bahwa profitabilitas memiliki pengaruh positif pada investment opportunity set, profitabilitas memiliki pengaruh positif pada kebijakan dividen, Investment Opportunity Set memiliki pengaruh negatif pada kebijakan dividen, dan profitabilitas berpengaruh pada kebijakan dividen melalui investment opportunity set. Penelitian ini juga diharapkan dapat memberikan implikasi praktis bagi investor sebagai agar dapat menjadi pertimbangan dalam berinvestasi dan menambah pengetahuan dengan mengetahui faktor-faktor yang memengaruhi kebijakan dividen. Penelitian ini juga diharapkan dapat membantu perusahaan dalam menentukan suatu keputusan yang dapat berpengaruh pada pertumbuhan perusahaan di masa depan dan kepercayaan investor terhadap prospek perusahaan.

\section{SIMPULAN}

Profitabilitas berpengaruh positif pada investment opportunity set. Hal ini berarti bahwa semakin tinggi profitabilitas, maka akan meningkatkan investment opportunity set. Profitabilitas berpengaruh positif pada kebijakan dividen. Hal ini berarti bahwa semakin tinggi profitabilitas, maka akan meningkatkan kebijakan dividen perusahaan. Investment Opportunity Set berpengaruh negatif pada 
kebijakan dividen. Hal ini menunjukkan jika investment opportunity set perusahaan semakin besar maka semakin rendah dividen yang dibayarkan. Artinya, jika investment opportunity set meningkat maka akan berpengaruh pada menurunnya kebijakan dividen. Profitabilitas berpengaruh pada kebijakan dividen melalui investment opportunity set. Investment opportunity set mampu memediasi pengaruh profitabilitas terhadap kebijakan dividen. Hal ini menunjukkan bahwa profitabilitas akan memberikan dampak yang signifikan pada kebijakan dividen jika dimediasi oleh investment opportunity set.

\section{REFERENSI}

Afriadi. (2016). Pengaruh Kebijakan Dividen, Kebijakan Hutang, Profitabilitas, dan Likuiditas terhadap Investment Opportunity Set (Studi Empiris pada Perusahaan Manufaktur yang Terdaftar di Bursa Efek Indonesia Tahun 2011-2014). E-Jurnal Universitas Negeri Padang, 4(1), 1-28.

Anam, B. S., Arfan, M., \& M. Shabri. (2016). Pengaruh Profitabilitas dan Set Kesempatan Investasi terhadap Kebijakan Dividen Tunai pada Perusahaan Manufaktur di Indonesia. Jurnal Magister Akuntansi Pascasarjana Universitas Syiah Kuala, 5(3), 20-29.

Anjarsari, Dewi, Dheasey Amboningtyas, dan P. D. P. (2018). The Impact of Retained Earnings As An Intervening Variable In The Implementation of Free Cash Flow, Funding Policies, Profitability And Collateral Assets As A Benchmark For Dividend Policy (The empirical study of Manufacturing Companies listed on the IDX . Journal of Management. ISSN : 2502-7689, 4(4), 1-17.

Anugrah, A. D. P., \& Bagus Nurcahyo. (2009). Analysis of the Effect of Investment Opportunity Set ( IOS ) on Analysis of the Effect of Investment Opportunity Set ( IOS ) on Return Stock Company Manufacturing Sector. Jurnal Universitas Gunadarma.

Arjana, I. P. P. H., \& I.D.G. Dharma Suputra. (2017). Pengaruh Profitabilitas, Leverage, Ukuran Perusahaan dan Corporate Social Responsibility Pada Kebijakan Dividen. E-Jurnal Akuntansi Universitas Udayana, 21(3), 20212051. https://doi.org/10.24843/EJA.2017.v21.i03.p12

Azmi, M. N., \& Agung Listiadi. (2014). Analisis Pengaruh Profitabilitas Dan Ios Terhadap Kebijakan Dividen Dengan Likuiditas Sebagai Variabel Moderasi Pada Perusahaan Manufaktur. Jurusan Jurnal Ilmu Manajemen Universitas Negeri SurabayaU, 2(3), 990-1001.

Baskin, J. (1989). Tests of Capital Structure Order Hypothesis Pecking. Financial Management Association International, 18(1), 26-35.

Bhattacharya, S. (1979). Imperfect Information, Dividend Policy, and The Bird in The Hand Fallacy. Journal of Economics, 10(1), 259-270.

Bista, N. B., N. R. Bartaula, O. Shrestha, P. Gnawali, Lamichhane, P., \& P. Parajuli. (2018). Impact of Corporate Governance on Dividend Policy of Nepalese Enterprises. Business Governance and Society, 377-397. https:/ / doi.org/10.1007/978-3-319-94613-9

Ginting, S. (2018). Pengaruh Likuiditas, Profitabilitas, dan Leverage terhadap Kebijakan Deviden pada Perusahaan LQ45 yang terdaftar di Bursa Efek Indonesia. JWEM STIE MIKROSKIL, 8(2), 195-204. 
Gunawan, F. S., \& Tobing, W. R. L. (2018). The Effect of Profitability, Liquidity, and Invesment Opportunities on Dividend Policy. South East Asia Journal of Contemporary Business Economics and Law, vol 15(5), 189-195.

Haryetti, \& Ekayanti, R. A. (2012). Pengaruh Profitabilitas, Investment Opportunity Set, dam Pertumbuhan Perusahaan terhadap Kebijakan Dividen pada Perusahaan LQ45 yang terdaftar di Bursa Efek Indonesia. Jurnal Ekonomi Universitas Riau Kampus Bina Wydia, 20(3), 1-18.

Hasana, Rawiyatul, Mardani Ronny Malavia, \& Wahono, B. (2018). Pengaruh Free Cash Flow, Profitabilitas, Likuiditas dan Leverage terhadap Kebijakan Dividen pada Perusahaan Food and Beverage yang Terdaftar di Bursa Efek Indonesia (BEI) Periode 2014-2016. E-Jurnal Riset Manajemen Fakultas Ekonomi Dan Bisnis Universitas Islam Malang, 7(12), 88-102.

Jensen, M.C.; Meckling, W. H. (1976). Theory of the firm: Managerial behavior, agency cost, and capital structure. Journal of Financial Economics, 3(4), 305-360.

Kajola, S. O., Adewumi, A. A., \& Oworu, O. O. (2015). Dividend Pay-Out Policy and Firm Financial Performance: Evidence from Nigerian Listed NonFinancial Firms. International Journal of Economics, Commerce and Management United Kingdom, III(4), 1-13.

Kaźmierska, B., \& Jóźwiak. (2015). Determinants of Dividend Policy: Evidence from Polish Listed Companies. Procedia Economics and Finance, 23(2015), 473-477.

Khalid, S., \& Mobeen Ur Rehman. (2015). Determination of Factors Effecting the Dividend Policy of Organizations. International Journal of Information Business and Management, 7(3), 319-334.

Mawutor, J. K. M., \& Embele Kemebradikemor. (2015). Analysis of the Relationship Between Profitability and Dividend Policy of Banks on the Ghana Stock Exchange. International Journal of Empirical Finance, 4(7), 407-417.

Miller, M. H., \& Franco Modigliani. (1961). Dividend Policy, Growth, and the Valuation of Shares. The Journal of Business, 34(4), 411-433. https://doi.org/10.1016/S1877-1203(10)70085-9

Natalia, D. (2013). Pengaruh Profitabilitas dan Kesempatan Investasi terhadap Kebijakan Dividen pada Perusahaan Manufaktur yang Terdaftar di BEI. Skripsi Universitas Padang.

Prakoso, G. A. (2016). Pengaruh Profitabilitas, Investment Opportunity Set dan Pertumbuhan Perusahaaan Terhadap Kebijakan Dividen Pada Perusahaan LQ-45 yang Terdaftar di BEI. Skripsi Fakultas Ekonomi Universitas Negeri Yogyakarta.

Rahmawati, A. D. (2012). Pengaruh Profitabilitas terhadap Kebijakan Dividen dengan Investment Opportunity Set sebagai Variabel Intervening (Studi Empiris: Perusahaan Manufaktur yang Listed di Bursa Efek Indonesia). Skripsi Fakultas Ekonomi Universitas Jember, 1-72.

Saputro, A. A., \& Lela Hindasah. (2007). Pengaruh Kebijakan Pendanaan, Deviden dan Profitabilitas Perusahaan terhadap Set Kesempatan 
Investasi (IOS). Jurnal Akuntansi Dan Investasi Universitas Muhammadiyah Yogyakarta, 8(1), 58-71.

Sari, N. K. A. P., \& Budiasih, I. G. A. . (2016). Analisis Pengaruh Investment Opportunities, Leverage, Risiko Pasar dan Firm Size terhadap Dividend Policy (Pada Perusahaan Manufaktur yang Terdaftar di Bursa Efek Indonesia Periode Tahun 2011 - 2014). E-Jurnal Akuntansi Universitas Udayana, 15(3), 2439-2466.

Sari, R. R., Harjum, M., \& Syuhada Sofyan. (2014). Analisis Pengaruh Investment Opportunities, Leverage, Risiko Pasar Dan Firm Size Terhadap Dividend Policy ( Pada Perusahaan Manufaktur yang Terdaftar di Bursa Efek Indonesia Periode Tahun 2011 - 2014 ). E-Jurnal Universitas Diponegoro, 1-12.

Sarmento, J. N. L., Kertahadi, \& Nila Firdausi Nuzuli. (2014). The Effects of Investment Opportunity Set (IOS) And Corporate-Financing on Dividend Payout Policy (A Study on Automotive and Components Companies Listed in Indonesia Stock Exchange Period 2009-2011). Jurnal Administrasi Bisnis (JAB), 13(2), 1-17.

Siboni, Z. M., \& Mohammad Reza Pourali. (2015). The Relationship Between Investment Opportunity, Dividend Policy and Firm Value in Companies Listed in TSE: Evidence from IRAN. European Online Journal of Natural and Social Sciences, 4(1), 263-272.

Silaban, Dame Prawira, \& Purnawati, N. K. (2016). Pengaruh Profitabilitas, Struktur Kepemilikan, Pertumbuhan Perusahaan, dan Efektivitas Usaha terhadap Kebijakan Dividen pada Perusahaan Manufaktur. E-Jurnal Manajemen Unud, 5(2), 1251-1281.

Singla, H. K., \& Pradeepta Kumar Samanta. (2018). Determinants of dividend payout of construction companies: a panel data analysis. Journal of Financial Management of Property and Construction, 1-21. https://doi.org/10.1108/JFMPC-06-2018-0030

Subchan, \& Sudarman. (2010). Pengaruh Kebijakan Utang, Kebijakan Dividen, Risiko Investasi Dan Profitabilitas Perusahaan Terhadap Set Kesempatan Investasi. Jurnal Bisnis Dan Ekonomi, 18(33), 1-20.

Subramaniam, R., Susela Devi, \& Marimuthu, M. (2011). The Usefulness of Measurement Equivalence in Psychological Evaluation: A MetaAnalysis. African Journal of Business Management, 5(24), 10128-10143. https://doi.org/10.5897/ajbm11.687

Sugiyono. (2017). Metode Penelitian Bisnis. In Bandung: Alfabeta.

Thirumagal, P. G., \& Vasantha, S. (2017). Dividend Payout Determinants: Evidence from Indian Industries. International Journal of Pure and Applied Mathematics, 117(21), 811-829.

Titus, W. W., \& Ambrose Jagongo. (2015). Determinants of Dividend Policy in Kenya. International Journal of Arts and Entrepreneurship, 4(11), 71-80.

Wiagustini, N. L. P. (2010). Dasar-Dasar Manajemen Keuangan. Denpasar: Udayana University Press.

Yudiana, I. G. Y., \& I Ketut Yadnyana. (2016). Pengaruh Kepemilikan Manajerial, Leverage, Investment Opportunity Set dan Profitabilitas pada Kebijakan 
Dividen Perusahaan Manufaktur. E-Jurnal Akuntansi Universitas Udayana, 15(1), 112-141.

Yunisari, N. W., \& Ratnadi, N. M. D. (2018). Pengaruh Profitabilitas dan Kepemilikan Manajerial Pada Kebijakan Dividen dengan Likuiditas Sebagai Variabel Moderasi. E-Jurnal Akuntansi, 23, 379. https://doi.org/10.24843/eja.2018.v23.i01.p15 